\title{
PENDAMPINGAN KONSELING PEVENTIF KANKER SERVIKS BERBASIS HEALTHY CITY PADA KELOMPOK MAJELIS TAKLIM DI KECAMATAN BACUKIKI KOTA PAREPARE
}

\author{
Preventive Counseling Base Preventive Services Based On Healthy City At Majelis Taklim \\ Groups In District Bacukiki City Parepare
}

\author{
Makhrajani Majid, Ayu Dwi Putri Rusman \\ Program Studi Kesehatan Masyarakat, Universitas Muhammadiyah Parepare \\ (nhiniekmajid@ymail.com) \\ (ayudwiputri88@yahoo.co.id)
}

\begin{abstract}
ABSTRAK
Kanker serviks merupakan kanker yang banyak menyerang perempuan. Melihat perkembangan jumlah penderita dan kematian akibat kanker serviks, diperkirakan bahwa sekitar 10 persen wanita di dunia sudah terineksi Human Pappiloma Virus (HPV). Muncul fakta baru bahwa semua perempuan mempunya risiko untuk terkena infeksi HPV. Infeksi jenis HPV tertentu merupakan penyebab utama kanker serviks hampir 20-100 kali lipat dan kebanyakan diderita oleh perempuan, terutama pada kelompok umur muda. Tujuan penelitian ini untuk membentuk team untuk melakukan kegiatan pendampingan Konseling Preventif Kanker Serviks yang bekerjasama dengan kelompok majelis taklim dan pementukan pos kesehatan dalam melakukan pelayanan yang baik kepada masyarakat. Metode penelitian yang dilakukan dalam tahap identifikasi kepada masyarakat Kelurahan Lapadde dan Kelurahan Bumi Harapan dan tahap implementasi pelayanan kesehatan nantinya akan dibentuk pos kesehatan sebagai media untuk mengontrol perubahan sikap dan pengetahuan masyarakat sebagai upaya preventif kanker serviks. Metode pengabdian kepada masyarakat ini berupa pendampingan konseling preventif dalam bentuk fisik dan intevensi terhadap perubahan sikap dan pengetahuan tentang kanker serviks yang berbasis healthy city. Hasil penelitian ini adalah terbentuknya kelompok preventif (pos kesehatan) bekerja sama dengan pihak mitra dalam bentuk layanan kesehatan berupa pendampingan, berdasakan hasil yang telah didapatkan melalui kegiatan penyuluhan tentang preventif kanker serviks tergolong baik hal ini ditunjukkan dengan bertambahnya pengetahuan dan adanya perubahan sikap untuk melakukan upaya pencegahan kanker seviks dengan menjaga kebesihan oran reproduksi mereka.
\end{abstract}

Kata kunci : Pendampingan konseling preventif, kanker serviks, majelis taklim, healthy city

\section{ABSTRACT}

Cervical cancer is a cancer that affects many women. Given the growing number of people and deaths from cervical cancer, it is estimated that about 10 percent of the world's women have been infected with Human Pappiloma Virus (HPV). There is a new fact that all women have a risk of HPV infection. Specific HPV infection is the leading cause of cervical cancer nearly 20-100 fold and is mostly afflicted by women, especially in younger age groups. The purpose of this study is to form a team to conduct assistance activities Counseling Preventif Cervical Cancer in cooperation with the group taklim assembly 
and post health post in doing good service to the community. The method of research conducted in identification phase to Lapadde and Harapan Bumi Harapan Subdistrict and the implementation phase of health service will be formed health post as media to control attitude change and public knowledge as preventive effort of cervical cancer. Methods of community service in the form of assistance in the form of preventive counseling physical and intevention of attitude changes and knowledge about cervical cancer based on healthy city. The results of this study is the formation of preventive groups (health posts) in collaboration with partners in the form of health services in the form of assistance, based on results that have been obtained through extension activities about cervical cancer prevention is good this is shown by the increase of knowledge and attitude changes to make efforts prevention of sevic cancer by maintaining the purity of their reproductive organs.

\section{Keywords: Counseling preventive counseling, cervical cancer, majelis taklim, healthy city}

\section{PENDAHULUAN}

Majelis taklim merupakan tempat pengajaran atau pendidikan agama islam yang paling fleksibel dan tidak terikat oleh waktu. Majelis taklim bersifat terbuka terhadap segala usia, lapisan atau strata sosial dan jenis kelamin. Watu penyelenggaraannya pun tidak terikat, bisa pagi, siang, sore atau malam. Tempat pengajarannya pun bisa dilakukan dirumah, mesjid, mushallah, gedung, Aula, Halaman dan sebagainya. Selain itu majelis taklim memiliki dua fungsi sekaligus, yaitu sebagai lembaga dakwah dan lembaga non-formal. Fleksibelitas majelis taklim inilah yang menjadi kekuatan sehingga mampu bertahan dan merupakan lembaga pendidikan islam yang paling dekat dengan Masyarakat. Majelis taklim juga merupakan wahana interaksi dan komunikasi yang kuat antara masyarakat awam dengan para mualim dan antara sesama anggota jamaah majelis taklim tanpa dibatasi oleh tempay dan waktu.
Pembangunan kesehatan bertujuan untuk meningkatkan kesadaran, kemauan dan kemampuan hidup sehat bagi setiap orang agar terwujud derajat kesehatan masyarakat yang setinggi-tingginya, sebagai investasi bagi pembangunan sumber daya manusia yang produktif secara sosial dan ekonomi. Program kesehatan reproduksi merupakan upaya untuk membantu para perempuan agar memiliki pengetahuan, kesadaran, sikap dan perilaku kehidupan reproduksi sehat dan bertanggungjawab. Kesehatan reproduksi ini tidak saja bebas dari penyakit dan kecacatan, namun juga sehat mental dan sosial dari alat, sistem, fungsi serta proses reproduksi. Masalah kesehatan reproduksi menjadi kepedulian Nasional karena disadari bahwa dalam menghadapi berbagai masalah hidupnya mereka membutuhkan perhatian yang khusus pula.

Kanker serviks merupakan kanker yang banyak menyerang perempuan. Melihat perkembangan jumlah penderita dan kematian akibat kanker serviks, diperkirakan bahwa 
sekitar 10 persen wanita di dunia sudah terineksi Human Pappiloma Virus (HPV). Muncul fakta baru bahwa semua perempuan mempunya risiko untuk terkena infeksi HPV. Ineksi jenis HPV tertentu merupakan penyebab utama kanker serviks hamper 20-100 kali lipat dan kebanyakan diderita oleh perempuan, terutama pada kelompok umur muda.

Penyebab utama kanker leher rahim adalah infeksi HPV. Ineksi virus ini dapat menyerang siapa saja, mulai dari perempuan berusia 20 tahun sampai perempuan yang tidak lagi dalam usia produktif. Beberapa faktor risiko dari infeksi virus HPV ini antara lain perempuan yang menikah pada usia kurang dari 18 tahun berisiko 5 kali lipat terinfeksi virus HPV, perempuan dengan kativitas seksual tinggi dan berganti-ganti pasangan, perokok, memiliki riwayat penyakit kelamin, paritas (jumlah kelahiran), pemakaian alat kontrasepsi oral dalam jangka waktu lama. Telah banyak penelitian menemukan bahwa insidens kanker serviks pada usia muda makin meningkat dan tumor terlihat leboh agresif. Proporsi perempuan dibawah 35 tahun yang menderita kanker serviks meningkat dari $9 \%$ menjadi $25 \%$.

Selain data tersebut tentu masih banyak penderita kanker serviks yang belum teridentifikasi dengan jelas dan belum mendapatkan layanan yang sesuai dengan kebutuhan para penderita kanker. Terbatasnya pengetahuan masyarakat mengenai kanker serviks menjadi salah satu penyebab permasalahan tersebut. Oleh karena itu, perlu adanya pendampingan konseling preventif yang berbasis healthy city dengan melibatkan kelompok majelis taklim.

Keterlibatan multidisimpiler ilmu yang tergabung dalam kelompok majelis taklim dibutuhkan dalam proses pendampingan konseling kepada penderita kanker servis secara preventif sehingga pendampingan konseling yang dilakukan oleh kelompok majelis taklim akan menghasilkan data dan keputusan akurat mengenai upaya preventif yang dapat dilakukan oleh penderita kanker serviks yang berbasis healthy city.

Berdasarkan analisis situasi tersebut, maka perlu dilakukan pendampingan program pemberian konseling preventif kanker serviks berbasis Healthy City dimasyarakat dengan melibatkan kelompok majelis taklim. Program kemitraan masyarakat ini ditujukan kepada ketua RW, RT dan semua kelompok majelis taklim di Kota Parepare karena berdasarkan hasil observasi lapangan didapatkan bahwa masih minimnya pengetahuan dari masyarakat tentang upaya preventif yang dilakukan untuk pencegahan kanker serviks. Sehingga upaya yang kami lakukan ini secara rill juga sangat dibutuhkan oleh pemerintah Kota Parepare.

Berdasarkan analisis situasi tersebut maka perlunya dilakukan proses pendampingan konseling preventif kanker serviks berbasis 
healty city dan pembentukan pos kesehatan sebagai media atau tempat pelayanan konseling preventif yang optimal. Tujuan pendampingan dalam kegiatan ini diharapkan mampu memberikan pengetahuan dan perubahan sikap serta kenyamanan dalam melakukan konseling sebagai upaya untuk menjaga system reproduksi mereka.selain itu dengan ada pos kesehatan akan lebih mudah dan mengontrol perubahan perkembangan kesehatan yang berbasis healthy city.

\section{METODE}

Penelitian ini merupakan penelitian dskriptif kualitatif untuk memehami dan memperoleh gambaran yang terjadi dilapangan.

Metode pendampingan

a. Persiapan, inventarisasi dan pembentukan kelompok mitra (Sosialisasi pada kelompok majelis taklim)

b. Pembentukan pos kesehatan sebagai media atau tempat untuk program konseling preventif untuk kelompok majelis taklim.

c. Pendampingan bersama pada mitra tentang konseling preventif kanker serviks berbasis healthy city dengan memberikan penyuluhan agar kesehatan masyarakat melalui perilaku hidup sehat dan bersih dapat terpeliharan dengan baik.

d. Pemberian pelatihan dalam melakukan konseling untuk upaya preventif kanker serviks e. Publikasi dilakukan melalui media cetak dan elektronik

f. Evaluasi kegiatan konseling dalam upaya preventif berupa penyuluhan agar kesehatan masyarakat berupa perilaku hidup bersih dan sehat akan tetap terpelihara dengan baik.

g. Pembuatan laporan kegiatan program.

Metode pendekatan yang digunakan pada program ini, sesuai dengan keadaan yang terjadi di masyarakat sehingga perlunya dilakukan pengembangan metode yang intensif berupa pendampingan konseling preventif kanker serviks berbasis healthy city sehingga mereka mampu memiliki tingkat pengetahuan yang baik serta pemahaman nyang baik sehingga dapat melakukan komunikasi yang lebih intensif sehingga mereka memiliki kemandirian untuk dapat melakukan perilaku hidup sehat dan bersih.

Selanjutnya yang paling penting pada pendampingan konseling Preventif ini adalah terbentuknya pusat pemberi layanan kesehatan untuk melalukan konseling masalah reproduksi yang dirasakan oleh semua kaum perempuan. Selanjutnya dengan adanya media berupa pos kesehatan akan lebih meningkatkan upaya preventif dari peningkatan penderita kanker serviks.

Partisipasi mitra dalam pelaksanaan program ini diikutsertakan secara aktif. Mulai dari pembentukan kelompok mitra, dalam hal ini pendampingan yang dilakukan semua anggota 
diikutsertakan, bukan hanya itu dalam penyusunan program Konsenseling preventif semuanya diserahkan kepada mitra. Termasuk dalam hal keuangan baik yang masuk maupun yang keluar semuanya diserahkan kepada kelompok mitra.

Metode Pelaksanaan

a. Sosialisasi

Sosialisasi dilakukan kepada mitra agar mereka mengerti dan tertarik untuk mengikuti kegiatan pendampingan tersebut.

b. Rekruitman kelompok majelis taklim

Rekruitmen merupakan proses pendataan kelompok majelis taklim untuk mengikuti proses pendampingan melalui tahapan pemetaan, kunjungan kelompok majelis taklim, pendekatan kepada masyarakat yang tentunya dilakukan sesuai dengan kondisi masyarakat setempat.

\section{Identifikasi kebutuhan}

Identifikasi pada upaya preventif kanker serviks yang dilakukan untuk menggali informasi mengenai latar belakang permasalahan dan kebutuhan konseling preventif yang berbasis healthy city. Kegiatan ini memiliki tujuan sebagai berikut:

1) Fungsi penyaringan untuk memberikan informasi kepada masyarakat khususnya para remaja melalui kelompok majelis taklim untuk meningkatkan tingkat pengetahuan, kesadaran serta sikap untuk menuju masyarakat yang sehat.
2) Fungsi perencanaan konseling sesuai dengan kebutuhan dari mitra.

3) Fungsi monitoring untuk mengukur kemajuan pendampingan untuk memonitor perkembangan komunitas dari mitra.

4) Fungsi evaluasi program untuk mengetahui sejauh mana program pendampingan dapat tercapai.

\section{Pembentukan pos kesehatan}

Program ini merupakan bentuk sarana pada saat memberikan pelayanan kesehatan pada masyarakat yang memiliki remaja putri yang tergabung dalam sebuah wadah disebut majelis taklim, dengan pembentukan pos kesehatan ini maka penyelenggaraan pemberian layanan kesehatan dalam bentuk konseling dapat memberikan kenyamanan dalam melakukan konsultasi kesehatan memberikan kenyamanan dalam beraktivitas sehingga kegiatan yang dilakukan melalui konseling dapat dipahami dengan baik dan efisien dari kelompok majelis taklim.

Konseling preventif kanker serviks berbasis healthy city untuk kelompok majelis taklim dilakukan untuk lebih memperhatikan organ reproduksi para remaja sehingga mereka dapat melakukan upaya preventif kanker serviks. Konseling yang diberikan dengan berorientasi pada para remaja agar mampu meningkatkan pengetahuan dan pemahaman mereka dalam melakukan perilaku hidup bersih dan sehat utamanya pada kebersihan dari sistem 
reproduksi. Kebersihan organ reproduksi merupakan keadaan organ seksual yang bebas dari kotoran dan infeksi. Menjaga kebersihan organ reproduksi saat menstruasi adalah cara menjaga kebersihan organ-organ seksual atau alat reproduksi saat menstruasi agar terterbebas dari suatu infeksi dan penyakit. Tujuan dari perawatan kebersihan organ reproduksi adalah pemeliharaan kebersihan dan kesehatan individu yang dilakukaan selama menstruasi, sehingga terhindar dari gangguan alat reproduksi dan mendapatkan kesejahteraan fisik dan psikis serta meningkatkan derajat kesehatan seseorang. Memelihara tingkat kebersihan selama periode menstruasi membantu menimalisir bau tidak sedap dan infeksi akibat tidak dijaganya kebersihan organ reproduksi.

Kegiatan pendampingan yang dilakukan ini terhadap kelompok majelis taklim pada penelitian dan pengabdian masyarakat ini diharapkan akan mendapatkan hasil yang maksimal dimulai pada perencanaan konseling yang nantinya akan disesuaikan dengan kondisi kelompok makelis taklim. Disamping itu pembentukan pos kesehatan diharapkan juga akan lebih meningkatkan tingkat pengetahuan dan sikap masyarakat tentang pencegahan kanker serviks. Selanjutnya dapat memberikan informasi kepada masyarakat khususnya para remaja tentang bagaimana perilaku perawatan organ reproduksi serta bagaiamana pencegahan terhadap penyakit kanker serviks. Dan dapat menambah wawasan mengenai perilaku perawatan organ reproduksi dalam mencegahan kanker serviks yang dapat memperkaya khasanah ilmu pengetahuan dalam hal penelitian serta memperoleh kesempatan untuk menambah pengalaman dalam melakukan pengamatan.

\section{HASIL}

Pencegahan kanker serviks yang paling efektif adalah melalui pendeteksian dini dengan pemeriksaan pap smear yang biasa mendeteksi pertumbuhan sel-sel yang akan menjadi sel kanker. Semakin dini sel-sel abnormal terdeteksi, semakin rendah risiko seorang menderita kanker mulut rahim. Pap smear test adalah suatu pemeriksaan yang aman, murah, dan telah dipakai bertahun-tahun untuk mendeteksi kelainan sel-sel di mulut rahim. Tes ini pertama kali ditemukan oleh George Papinicalou. Metode tes ini adalah pemeriksaan sel-sel yang diambil dari cairan mulut rahim dan kemudian diperiksa dengan mikroskop untuk melihat perubahan-perubahan yang terjadi dari sel tersebut. Tes ini tidak memakan banyak waktu, hanya beberapa menit. Pemeriksaan ini dilakukan untuk mendeteksi sel kanker lebih awal pada pasien yang tidak memberian keluhan. Sel kanker dapat diketahui pada secret yang diambil dari porsi serviks. Pemeriksaan ini harus mulai dilakukan pada wanita usia 18 tahun atau ketika telah melakukan aktivitas seksual sebelum itu. Setelah tiga kali hasil pemeriksaan pap 
smear setiap tiga tahun sekali sampai usia 65 tahun. Pap smear dapat dideteksi sampai $90 \%$ kasus kanker leher rahim secara akurat dan dengan biaya yang tidak mahal, akibatnya angka kematian akibat kanker leher rahim pun menurun sampai $50 \%$. Setiap wanita yang telah aktif secara seksual sebaiknya menjalani pap smear secara teratur yaitu 1 kali setiap tahun. Apabila selama 3 kali berturut-turut menunjukkan hasil pemeriksaan yang normal, maka pemeriksaan pap smear bisa dilakukan setiap 2 atau 3 tahun sekali. Hasil pemerisaan pap smear adalah sebagai berikut (Prayetni, 1999) invasive (kanker telah menyebar kelapisan serviks yang lebih dalam atau ke organ tubuh lainnya).

a. Normal

b. Displasia ringan (perubahan dini yang belum bersifat ganas)

c. Displasia berat (perubahan lanjut yang belum bersifat ganas)

d. Karsinoma in situ (kanker terbatas pada lapisan serviks paling luar)

e. Kanker

Berikut ini ada beberapa hal yang perlu dilakukan untuk menghindarkan wanita dari kemungkinan terkena kanker mulut rahim:

1. Pemeriksaan teratur, apabila anda wanita dewasa yang melakukan hubungan yang teratur, lakukan pap smear test setiap dua tahun ini dilakukan sampai usia 70 tahun.

2. Waspadai gejalanya, segera hubungi dokter jika ada gejala-gejala yang tidak normal seperti perdarahan, terutama setelah aktivitas sosial.

3. Hindari merokok, wanita sebaiknya tidak merokok, karena dapat merangsang timbulnhya sel-sel kanker melalui nikotin dikandung dalam darah. Risiko wanita perokok terkena kanker mulut rahim adalah 4-13 kali lebih besar dibandingkan weanita yang bukan perokok. Diperkirakan nikotin memberikan efek toksik pada sel epitel, sehingga memudahkan masuknya mutagen virus.

4. Menghindari kebiasaan, yaitu menghindari kebiasaan pencucian vagina dengan menggunakan obat-obatan maupun deodorant karena akan mengakibatkan iritasi di serviks yang merangsang terjadinya kanker.

5. Hindari pemakaian bedak pada vagina wanita usia subur, karena justru biasa mengakibatkan kanker ovarium. Jangan menggunakan estrogen pada wanita yang terlambat monopouse.

\section{PEMBAHASAN}

Kegiatan pengabdian ini merupakan implementasi program yang dilakukan sebagai berikut:

a. Pembentukan kelompok mitra dengan dengan majelis taklim yang terdapat dikedua kelurahan yaitu kelurahan Lapadde dan Bumi Harapan diketua oleh masing-masing ketua majelis taklim dibantu oleh beberapa 
anggota. Hasilnya dapat berupa pengembangan potensi keterampilan, komunikasi, sikap dan tingkat pengetahua yang optimal. Dengan adanya program ini diharapkan kelompok majelis taklim mampu memberdayakan dirinya sendiri baik secara individu maupun secara kelompok agar mampu mewujudkan derajat kesehatan yang setinggi-tingginya melalui upaya preventif.

b. Selanjutnya untuk kelompok majelis taklim sebagai mitra juga mampu melakukan pengembangan dalam hal sarana dan prasarana serta kompetensi ilmiah dalam pemberian konseling preventif dan peningkatan pendidikan dan pengetahuan yang optimal

c. Pendampingan dilakukan melalui bimbingan konseling dan pendampingan pelayanan kesehatan dilakukan dengan memberikan penyuluhan PHBS dalam menjaga kebersihan sistem reproduksi.

\section{KESIMPULAN}

Proses pendampingan konseling preventif kanker serviks berbasis healthy city berjalan dengan baik dan terjadi perubahan perilaku dan pemahaman masyarakat terkait dengan PHBS untuk menjaga kebersihan reproduksi mereka. Pembentukan pos kesehatan sebagai media/ tempat pelayanan konseling preventif yang optimal dilakukan, selain itu, pemberian media kepada kelompok mitra dapat memudahkan dalam proses konseling. Untuk itu disarankan kepada pelayanan kesehatan agar lebih meningkatkan kegiatan pendidikan kesehatan tentang deteksi dini kanker serviks, metode IVA oleh tenaga kesehatan kepada Wanita Usia Subur melalui penyuluhan konseling serta mengajak untuk ikut melakukan pemeriksaan IVA. Disarankan juga untuk memperluas sasaran promosi kesehatan, tidak hanya pada ibu tetapi juga pada keluarga agar dapat mendukung istri atau anak perempuan untuk melakukan pemeriksaan IVA agar pengetahuan kesehatan yang diberikan sejak dini akan dipraktekkan.

\section{DAFTAR PUSTAKA}

1. Asliana. Hubungan Tingkat Stres dengan Siklus Menstruasi pada Remaja Khususnya pada Siswi SMK Negeri 1 Watampone. [Skripsi] Makassar: Fakultas Kesehatan Masyarakat Universitas Hasanuddin; 2010.

2. Blackshare. Pengertian Remaja. [Serial Online]. 2012. [Diakses 10 Maret 2017]. Available at: (http://www.inforemaja.com.html.)

3. Koes, Indrawati. Upaya Meningkatkan Pengetahuan tentang Kebersihan Organ Reproduksi Siswi SMPN 10 Surabaya. [Serial Online]. 2015. [Diakses 08 April 2017]. Available at: (http://dispendik.surabaya.go.id)

4. Lumongga, Namora. Psikologi Kesehatan Reproduksi. Jakarta: Kencana Prenada Media Group; 2013. 
5. Notoatmodjo, Soekidjo. Promosi Kesehatan dan Ilmu Perilaku. Jakarta: PT Rineka Cipta; 2010.

6. Puspitasari, Y. Anatomi Fisiologi Sistem Reproduksi Perempuan. [Serial Online]. 2010. [Diakses 10 Maret 2017]. Available at:

(http://yunitapuspitasari.wordpress.com/201

0/05/24/anatomi-fisiologi-sistem-reproduksiperempuan)

7. Ranirifki. Makalah Remaja dan Permasalahannya. [Serial Online]. 2014. [Diakses 14 Maret 2017]. Available at: (http://ranirifki.blogspot.com).

8. Sabrina. Metode Penelitian. [Serial Online]. 2013. [Diakses 20 Mei 2017]. Available at: (http://bellashabrina.wordpress.com/2013/09 /17/5-skala-pengukuran-sikap/)

9. Suparyanto. Konsep Perilaku. [Serial Online]. 2010. [Diakses 20 Mei 2017]. Available at: (http://drsuparyanto.blogspot.com/2010/09/konsepperilaku-1.html.)
10. Susanti, Erni. Tips Kesehatan untuk Keluarga. [Serial Online]. 2013. [Diakses 10 Mei 2017]. Available at: (http://tips-sehatkeluarga-

bunda,blogspot.com/2013/08/menjagakesehatan-reproduksi-perempuan.html)

11. Surya. Hubungan Pengetahuan Kesehatan Reproduksi Remaja Putri dengan Perilaku Personel Hygiene. [Serial Online]. 2010: 03(VII). [Diakses 02 Mei 2017]. Available at: (http://www.slideshare.net.id)

12. Widya, Nurlita. Gambaran Tingkat Pengetahuan dan Perilaku Menjaga Kebersihan Organ Genetalia Eksterna pada Siswi MI Pembangunan [Skripsi]. Jakarta: Fakultas Kedokteran dan Ilmu Kesehatan Universitas Islam Negeri Syah Hidayatullah: 2014. [Serial Online]. Available at: (http://widyanurlita.fkik.pdf)

13. Wikipedia. Wikipedia Organ Reproduksi. [Serial Online]. 2014. [Diakses 14 Maret 2017]. Available at: (http://id.m.wikipedia .org/wiki/remaja) 